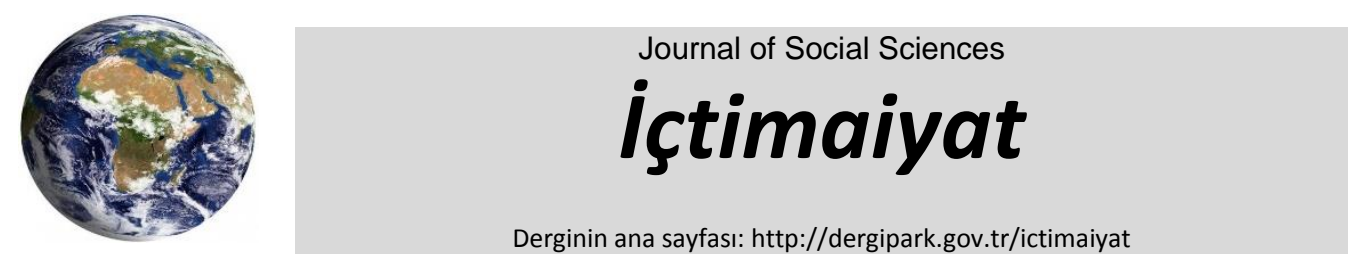

Araştırma Makalesi • Research Article

\title{
TÜRK DEVLETININ DEVRIMSEL DÖNÜŞÜMÜNE KATKI: MEŞRUTIYET DÖNEMI DINI MUHALEFET
}

\section{Contribution to the Revolutionary Transformation of the Turkish State: Religious Opposition during the Constitutional Era}

Mehmet Uğraş*

ORCID: 0000-0002-6667-189X. Afyon Kocatepe Üniversitesi, Fen Edebiyat Fakültesi, Sosyoloji Bölümü, Afyon/Türkiye.

MAKALE BILGISi

Makale Geçmişi:

Başvuru tarihi: 9 Mayıs 2018

Düzeltme tarihi: 12 Mayıs 2018

Kabul tarihi: 14 Mayıs 2018

Anahtar Kelimeler:

Dini Muhalefet, reformist ulema, II.

Meşrutiyet, iktidar ilişkileri, toplumsal iktidar.
ÖZ

Meşrutiyet dönemi Osmanlı hanedanının siyasal iktidarının son demlerini yaşadığı devirdir. Bu dönemde siyasal iktidarın dönüşümünü sağlayan birçok parametre bulunmaktadır. Sebepleri ikiye ayırabiliriz: Dışsal ve içsel. Dışsal sebepler genel olarak konjonktürle ilgilidir. İçsel sebepler ise bir iktidar-direniş diyalektiği çerçevesinde değerlendirilmelidir. Garip bir şekilde II. Abdülhamid'in iktidarını bitiren direnç, bir çeşit dini muhalefet araçlarıydı. Bu minvalde ittihatçı ulema oldukça etkin bir rol üstlenmiştir. Bu çalışmada bu direncin katkılarıyla oluşan devrimsel bir dönüşümün izleri takip edilerek, Osmanlı devlet mekanizmasının anayasa merkezli bir parlamenter rejime nasıl evirildiği gösterilmeye çalışılacaktır.
Article history:

Received 9 May 2018

Received in revised form 12 May 2018

Accepted 14 May 2018

\section{Keywords:}

Religious opposition, reformist cleric, II.

Constitutional era, power relations, social power.

\section{ABSTRACT}

Ottoman dynasty experienced the last periods of the political power in the II. Constitutional era (II. Meşrutiyet). In this period there are many parameters that provide the transformation of political power. We divide the reasons into two: external and internal. External causes are generally related to conjuncture. Internal factors should be considered within the framework of a dialect of power-resistance. Strangely, resistance, which ended II. Abdulhamid's rule, was a sort of religious opposition. In this way, the reformist cleric (ittihatçı ulema) has played a very active role. In this study, we will try to show how the Ottoman Empire has transformed a constitutional-centered parliamentary regime by following the traces of a revolutionary transformation caused by these resistance contributions.

\footnotetext{
${ }^{*}$ Sorumlu yazar/Corresponding author. e-posta: ugras_0@hotmail.com
} 


\section{Giriş}

iktidar ilişkilerinin mahiyeti aslında toplumsal güçlerin ${ }^{1}$ siyasi alana hâkim olma çabalarıyla ilgilidir. Dolayısıyla iktidarı ele geçiren unsurun galip geldiği diğer unsurlara nüfuzunun sınırlarında yenik güçlerin direnci bulunmaktadır. (Barbalat, 1985: 536). Teorik olarak belirtilen bu direncin Osmanlının son dönemine yansıması, Türk devletinin 31 Mart olayıyla birlikte nasıl bir net dönüşüme uğradığını görebilmemiz açısından ele alacağımız önemli bir nazari çerçeveye göre şekillenecektir. Bu çerçeveyi kapsayan en önemli unsur dini muhalefet meselesidir. Devleti dönüştüren hamlelerin meşruiyetini sağlayacak yegâne unsurun bu topraklar için din olduğunu söylemek bir abartı değildir. Dolayısıyla batılı dönüşüm perspektifinin karşısındaki geleneğin, iktidarı sınırladığı yer, Türk toplum ve devlet yapısının muhtevasının dönüşümü açısından düşünülürse dini muhalefetin çok önemli bir direnç kaynağı olduğunu söyleyebiliriz. Burada bahsedilmesi gereken en temel nokta ise dini muhalefetin aynı zamanda Osmanlı hanedanının iktidarına son verdiği gerçeğidir. Ama bu süreç hilafet kaynaklı kurumsal bir dini muhalefetin yoğunlaşmasıyla gerçekleşmiştir. 31 Mart olayından sonra Cumhuriyetin ilanına kadar olan karışık ve kritik, iç-dış savaşların yoğun olduğu bir dönemde ise dinin direnci oldukça kültürel bir perspektif kazanmıştır. Daha sonra ise Cumhuriyet döneminde bu kültürel seyrin, dinin dogmatik alanına nüfuz eden gelişim ve gidişatın yoğunlaşmasıyla direnci daha farklı ve daha özelleşmiş alanlara sevk ettiğini müşahede edeceğiz.

Türkiye'de dini muhalefet meselesinin teorik-metodolojik çerçevede bir analizini yapma gereği duymamızın çeşitli sebepleri vardır. En önemli sebep dinin muhakkak tek bir yorumunun, tek bir yaşam biçiminin (kültür) olmaması ile ilgilidir. Bu bağlamda İslam düşünce geleneğinin kaynaklarını teşkil eden selefi düşünce, tasavvuf düşüncesi ve kelâmi-felsefi tarzın (Uludağ, 2012) Osmanlı toplumsal iktidarının zeminini de oluşturduğu söylenebilir. Ehli Sünnet perspektifinde Hanefilik mezhebinin oluşturduğu bir tasavvuf-kelam uzlaşısı geleneği (Şeker, 2013:253), modernliğin devlet ve toplum sınırlarında etkisiyle birlikte yeni kurulan Türk devletinin temellerini oluşturan Meşrutiyete karşı çok farklı tepki hamleleri gerçekleştirmiştir. Bu hamlelerin kapsamlı tespitini yapmak oldukça zordur. Ancak dini muhalefet nazariyesi çerçevesinde belirleyebileceğimiz birkaç davranış kalıbına göre bir şema oluşturabiliriz. Bu şema kesinlikle İslami düşünce tarzının farklııılarına göre şekillenecektir: Devrimsel tepki, sembolik muhalefet ve kalbi muhalefet. Dini muhalefetin bu üç boyutu "Türkiye'de dinin sosyolojik imkânının" (Aktay temellerini oluşturmuştur. Devrimciler genellikle temkin ve "temekkün" (Mustafa, 2001: 327) temelli bir sabır sürecini benimseyip imkânlar olgunlaştığında bir başkaldırı vizyonu edinmişlerdir. Bu imkânların ne zaman olgunlaşacağının ölçüsünü yapacak temel, muhalefet bilincini oluşturan zihniyetin şiddete başvurma, aceleci olma ve dünyevi hedeflere güdülenme gibi motivasyonlarıdır. Şeyh Ubeydullah isyanını buna örnek olarak gösterebiliriz. Sembolik muhalefet içinse ileride bahsedeceğimiz tarzda dinin bir takım sembol ve ritüelini hatta dogmatik özelliklerini muhafaza şeklinde gösterilen bir tavır tarzıdır. Buna örnek olarak da iTC'nin, ulemanın dini nüfuzunu kullanarak gerçekleştirdiği sembolik tepkileri gösterebiliriz. ${ }^{2}$ Üçüncü olarak da tasavvufi dünya görüşünü oluşturan Vahdet-i Vücut nazariyesi perspektifinde "her şeyi Allah'tan görmenin" felsefesi olarak açıklayabileceğimiz apolitik gibi duran ama aslında bireysel mikro alanlarda oldukça politik bir tepki tarzı olarak kalbi muhalefetten bahsedebiliriz. Bu üç muhalefet tarzı da siyasal alanda meşru yollarla yapılacağı gibi gayrı meşru yollarla da yapılabilir. İsyanın ölçüsü şiddetin ve haddi aşmanın kapsamı içinde değerlendiriliyorsa gayrı meşru ilan edilen muhalif hareket, eğer devrim güdümlü bir isyan örgütlenmesinden uzak duruyorsa ve dini bu minvalde yorumluyorsa tepkisini kültürel veya kalbi cephelerde sürdürmek durumundadır.

\footnotetext{
${ }^{1}$ Kavramın detayları için bkz. (Mann, 2012) Mann'a göre toplumsal iktidar ekonomi, siyaset, askeriye ve ideolojiden oluşan dört menşeden ibarettir. Bunlar bir coğrafyada bulunan irili ufaklı toplumsal grupların hangi motivasyonla birleştiklerine göre şekillenirler. Siyasal iktidarı oluşturan güç, Weber'in anladığı şekilde şiddetin meşru araçlarını elde etmekten daha fazla bir şeydir. Siyaset-din; askeriye-din-siyaset, ekonomi-siyaset-askeriye gibi çeşitli birleşmelerin ürünü olarak devletler doğar. Bunların bir bünyede özerk hale gelmeleri veya herhangi birinin aşkın ideoloji imkânlarını ele geçirmesi birbirinden farklı siyasal iktidarlar doğurmaktadır.

${ }^{2}$ Hutbeler, Hilafet risaleleri ve arizalar. Daha teferruatlı bilgi için bkz. (Kara, 1998) ve (Kara, 1999).
} 
İslam tarihinde oluşan teokratik iktidarlar da fethedip yönettikleri memleketleri zor (force) kullanarak itikadi-iktidar çemberlerine sokmaya pek yanaşmamışlardır. Çoğunlukla kalbi ve gönüllü riayetin ${ }^{3}$ temellerini atmaya çalışmış, böyle bir yönetim tarzı benimsemişlerdir. Emeviler, Abbasiler, Selçuklular, Memlükler, Osmanlılar... bu hanedanların yönetim şekilleri büyük oranda gönüllü riayet esaslarına dayanmaktadır. Ancak ideolojik (İslami) sınırlarda değerlendirilen her bir Müslüman'ın veya dini grubun itikadi-siyasi ve kültürel alanlardaki mezhepsel veya siyasi itirazları iktidar tarafından çoğunlukla sert bir şekilde cevap bulmuştur. Osmanlı devletinden sonra yeni kurulan Türk devletinin de dini politikaları bu minvalde değerlendirilmesi gerekir. Türkiye'de dini muhalefet, Türkiye Cumhuriyeti Devletinin kuruluşundan günümüze, din ile ilgili reform, inkılap ya da politikalarına karşı kültürel veya devrimci bir karşı koyma biçimi olarak okumak gerekirse, bu sürecin ne şekilde geliştiği hakkında bir takım modernleşme tarihiyle ilgili noktalara değinmek gerekmektedir.

Osmanlı'da İslami hareketler tek biçimli veya bütünleşik değildir. Osmanlı dönemi boyunca İslam çok çeşitli temsil pozisyonları edinmiştir. Bir başka deyişle imparatorluktaki Müslüman cemaatler heterojen ve çok boyutluydu. Bu çeşitlilikten doğan ortodoksi (Ehli Sünnet) ve mistik (Tasavvuf) ekoller farklı şekillerde ve rollerde bölgelerin ve cemaatlerin bütünleşmesine yardımcı oluyordu. İslam'ın Osmanlı döneminde çok biçimli veya çok boyutluluğu modern devletin karşısında bir İslam devrimine sebep olacak şartların oluşmasına engel olmuştur. (Karasipahi, 2009: 88). Sünni ideolojinin devrimsel bir tarz işletmemesinin altında yatan sebeplerden başka biri, onun Şiiliğin aksine entelektüelkurumsallaşmış bir imamet-hilafet teorisinin olmamasıdır (Karasipahi, 2009: 106). Yani halifenin kim olacağı meselesinden ziyade halifelik tavrının nasıl olacağı üzerinde durulmuştur. Bu anlamda halife belirleme işi kurumsal sınırlarının dışında mevcut kurumların (eğer dezenformasyon, bozulma, çözülme durumları varsa) ihyasına çalışmak başvurulacak tek siyasi tavırdır. Bunun aksine davranıp iktidarın meşruiyetini sorgulayarak onu devrim imkânlarının gerektiği gibi yerinden etme girişimleri ağır ve kanlı bir şekilde bastırılmıştır. Çünkü hiçbir dönemde bu isyanlar imparatorluk sınırlarda kapsamlı bir meşruiyete ulaşamamışlardır. ${ }^{4}$ Bu tarihi olgusal gerçeklik Meşrutiyet devri Osmanlısında, hatta Cumhuriyet Türkiye'sinde de baskındır. ${ }^{5}$ Dini muhalefetin ortaya çıkma potansiyeli açısından devlet çevrenin unsurlarını çeşitli yollarla denetim altında tutup rakip bir ideolojik tutumun yeşermesine engel olmaya çalışmıştır. Teknik ilerledikçe denetim politikaları taşraya nüfuzunu artırdıkça muhalefet potansiyeli olan unsurların kendi imkânlarından uzaklaşma gibi bazı gerçeklerle karşı karşıya kalmıştır.

Modernleşme devrinde Türkiye' de İslami hareketlerin yeniden diriliş idealini oluşturan merkez, dinin müesseseleşmiş hali olan câmilerden ziyade metin ve görsel medya unsurlarının kullanımıyla ve halkı eğitmek ve seferber etmek amacıyla oluşturulan entelektüel çevrelerdir. (Karasipahi, 2009: 90). Böyle bir anlayış aslında merkezci bir tutumdur. Halkın kendi imkânlarını kullanmaktan ziyade, halkı belli bir seviyeye eriştirmeye çalışarak böylece bir dini hareketlenme oluşturma anlayışı siyaset nazariyesi açısından kayda değer bir tutumdur. Bu çevrelerin Osmanlı tarihi boyunca varlıklarını sürdürdükleri zemin devlet-din bütünleşmesidir. Dolayısıyla batılılaşma endeksi kurumsal dönüşümlerin yaşandığı Tanzimat döneminden başlayarak İnkılap devrine kadar dinin unsurları (ulema)için devlet kademelerinde taşra-merkez arası kopuklukları gidermesi ve devletin meşruiyetini sürekli olarak sağlaması hasebiyle herhangi bir özerklikten bahsetmek mümkün değildir. Özerkliğin sağlanması tasavvuru ise laiklik ideolojisinin Fransız jakobenlerinin tarzına yakın bir şekilde sağlanmasıyla ortaya çıkmış ve gelişmiştir. Bu da İslami hareketlerin kendi alanlarına itilmesi ve kamusal alanlarda git gide varlığını kaybetmesi gibi bir sürecin işlemesine yol açmıştır.

\section{Dini Muhalefetin Dayanakları: Reform ve Gelenek}

\footnotetext{
${ }^{3}$ Kavram için Bkz. (Lukes, 2016: 155 )

${ }^{4}$ Burada Şeyh Bedreddin'in isyanı, sonuçları açısından Türkiye'de dini muhalefetin hangi sınırlarda gelişebileceği potansiyelini taşıması açsından işaret edilmesi gerek önemli bir vakadır. Sekülerleşme meselesi bu anlamda batıyla münasebetin ticari ve siyasi anlamda başladığı Lale devrinin önemli olayı Patrona Halil isyanından daha gerilere götürülebilir.

5 Türkiye'de devlet geleneğinin sürekliliği (Heper, 2012: 239) bu anlamda bir paralellik oluşturmaktadır.
} 
Osmanlı'da muhalefetin kaynağı, mevcudiyeti ve şekli ontolojik dünya görüşüne dayanmaktadır. Bu durum İslam diniyle yakından ilintilidir. Bir zihniyet meselesi olarak tasavvuf-kelam uzlaşısının oluşturduğu ibn Halduncu Osmanlı siyaset felsefesi (Şeker, 2013: 64); başkaldırı, devrim gibi iktidar hırsıyla neşet eden tepkisellikleri değersiz görmüştür. Osmanlı toplumunda bu sebeple bir muhalefet kurumsallaşması yaşanmamıştır. Muhalefet diyebileceğimiz hareketler çoğunlukla iktidara karşı devrimci bir tarzda yürütülürdü. Dolayısıyla muhalefet etmek isyan etmekle eş anlamlı algılanıyordu. Bunun için isyanların başlangıçları ne şekilde olursa olsun, sonu kanlı oluyordu. Ancak geç dönem Osmanlı'da batılılaşmanın etkisiyle durum değişmiştir. Devlet'e yönelik tepkiler ortada açıkça duran siyasi, ekonomik ve askeri sorunlar dolayısıyla daha görünür olmaya başlamıştır. Öyle ki, III. Selim döneminde Avrupa'ya gönderilen talebeler sistemin çatlaklarını görerek bu konuda yeni bir Osmanlılık şuuru oluşturmaya girişmişlerdir. Bu irili ufaklı tepkisellikler ileride yürütme organını etki etme ve onu ele geçirme hedefiyle padişaha karşı örgütlenmiştir. Siyasal gelişim evreleri hiç şüphesiz oldukça önemli detaylar içeren bir içeriğe sahiptir. Ancak, Genç Osmanlıların kısmi örgütlü eylemlerini ve düşüncelerini de önemini küçümsemeyip, Osmanlı'ya karşı Illk partileşmiş muhalefet olarak ìttihat ve Terakki Cemiyetini görerek Türkiye'de dini muhalefet meselesinin dayanaklarını aramaya buradan itibaren başlamak, sanıyoruz ki doğru olacaktır.

Jön Türklerin varlığını kuşatacak sihirli bir kelime bulmak gerekiyorsa, bu hiç şüphesiz 'hürriyet' olurdu. Hürriyetçi bakış son dönem Osmanlı entelektüelleri ${ }^{6}$ arasında tartışmasız yücelenen ve öncelenen bir tarzı teşkil ediyordu. Ancak bu konuda bir tasavvur birliğine ulaşılamamıştır. Bunu, aynı ifadenin farklı versiyonları arasındaki kavgada görebiliriz. Aslında 'manaların farklılı̆ına' bir vurgu söz konusuydu. Yani hürriyet, meşrutiyet, eşitlik gibi değerlerden anlaşılanlar farklı farklıydı. Dolayısıyla ortada bir söylem tartışması vardı diyebiliriz. Klasik Osmanlı söyleminin nüfuzunu kaybettiği dönemde, kaybetmesini oluşturan şartlar açısından düşünüldüğünde, hürriyet, terakki, muasırlaşma gibi kelimelerin Osmanlı şuurunun hayata yeninden döndürme projelerinde kullanılıyor olması garip bir çaba gibi görünmektedir. Çünkü kavramların mevcut tarihsel anlamları tedrici bir şekilde hegemonyasını hissettirecektir. Hilafet ve Saltanat şeklinde ifade edilen din-siyaset uzlaşısını temsil eden bir Osmanlı sisteminin mevcut siyasi terminolojisine rağmen, henüz ortaya atılmış batılı dünya görüşüne dayanan söylem kalıpları son dönem Osmanlı uleması tarafından İslam terminolojisinin teceddüt koşullarının sağlanmasına zemin hazırlamak için kullanılması oldukça ilginçtir. ${ }^{7} \mathrm{Bu}$, toplumun gelecek umutları açısından çok farklı ve öngörülmez sonuçlar doğurmuştur. Dolayısıyla batılılaşma kavramları böyle bir ortamda kendi yolunu çizerken tedrici bir tarz izlemektedir. O dönemde, kavramların ve araçların mevcut tarihsel anlamları, yani gerçek mahiyetleri anlaşıldıkça bir kısım ulemanın hatasından dönmesi ve eski savunduğuna kati muhalefet etmesi gibi tenakuz denilebilecek durumlarla karşılaşmak oldukça mümkündür. Bu şartlarda ulemayı muhalefet stratejilerine göre kategorize etmek çetrefil bir çaba olarak karşımızda durmaktadır. Ancak şu var ki, batılılaşma, hegemonyasını tedrici bir şekilde sürdürürken reformist duruşunu koruyan ulemayı bağımsız değişken olarak merkeze almak süreç içerisinde farklılaşan tepkileri daha net ölçmek açısından önemlidir. Yani iktidar cephesinin dini bir çevrenin sözcülüğüyle ve meşruiyet çabalarıyla epistemolojik ve metodolojik

\footnotetext{
${ }^{6}$ Malumdur ki, Osmanlı intelijansıyası, modernleşme devrinden önce medreselerde okutulan kelam, fikıh, akaid gibi ilimlerde ihtisas sahibi olanlar veya bu ilimlerin hayata-pratiğe aksetmesi olarak tanımlanabilecek tasavvufi 1stılahın tekke ve tarikat şeklinde kurumsallaşan yapılarının eğitim-irşat faaliyetleriyle yetiştirdiği zevat şeklinde iki bütünleşik toplumsal tipi kasteder. Modernleşme etkisi ise son dönem Osmanlı aydın lafz-1 mübareğiyle yeni bir öncü insan modeli ortaya çıkarmıştır. Kısaca bunlar bürokrat çevrelerdendir diyebiliriz. Buradan itibaren eski Osmanlı intelijansiyası (ulema) kendini bu modern hayata nasıl adapte ettiği-edebildiği-edemediği oldukça önemli bir sorunsaldır. Biz bu sorunsalın bir veçhesi olan dini muhalefet meselesine yoğunlaşmak durumundayız. Diğer önemli veçhesi ise entegrasyon meselesidir.

${ }^{7}$ Bunun sebebi sosyal iktidarın önemli ölçüde dönüşmesidir. Asabiyenin farklılaşması toplumun bütünleşmesini sağlayan temel motivasyonun değişmesi şeklinde ifade edebiliriz. Dini-ideolojik önceliklerin yerini ekonomik öncelikler almıştır. Dolayısıyla yeniden bu asabiyenin oluşması için bizzat ulema tarafından devlet merkezli dönüştürme çabaları sarf edilmiştir. Garip bir şekilde Cumhuriyet devrimi ve inkılap politikaları bu dönüştürme çabalarının sağladığı meşruiyet zeminiyle çok yakından ilintilidir.
} 
olarak dini hayatı düzenlemesi gerçeği önemli bir parametredir. ${ }^{8}$ Bu anlamda batıcılar kanadında içtihat mecmuası ve milliyetçiler kanadında ise islam mecmuasında aksedilen düşüncelerin oluştuğu dini reformistler dönüşümün kültür-anlam cihetlerinde köşe taşlarını temsil ederler.

Hürriyet ve eşitlik söylemlerinin dayandığı temel, bireylerin kişisel yaşamlarında neye inandığı ve neye tabi olduklarına bakmaksızın; tabi oldukları din, gelenek veya inancın kolektif bir devlet bilincine veya devlet bilincini geliştirecek bir mülke dönmemesi gerektiği hakkında laik bir anlayıştır. Dolayısıyla dini bilinci yükselten idealler hakkında tam kanaate sahip olan ulema, hürriyet söylemlerinin esas maksadını gördükleri zaman ona muhalif bir pozisyon almıştır. Jön Türkler son dönem Osmanlı toplumsal iktidarını dönüştürmek için bu anlayışa dayanarak (1) Padişah'ın bağımsızlığına dokunmama, (2) bireylerin inançlarına dokunmama, (3) dinin dünya işleriyle ilgilenmemesi gerektiği üzerine bir algıyla teba-iktidar ilişkileri açısından kritik bir dönüşüm süreci başlatmıştır. (Çavdar, 1991; 13). Böylelikle ideolojik-dini gücün imkânları, başta halife olmak üzere, faideli bilgiler, tekkeler, medreseler, âlimler, fakihler devletin kurumlarında geçer akçe olma durumundan yavaş yavaş uzaklaşmaya başlamıştır. Ulemanın merkezde nüfuzu kırılmıştır. Bu anlamda ideolojik gücün özerkleşmesinden ziyade, siyasi gücün özerkleşmesi durumundan bahsedilebilir.

\section{Abdülhamit Rejimi ve Ulema (1876-1909)}

Kayalı'ya göre $(2017 ; 602)$ bu dönemi istibdat veya baskı dönemi olarak nitelemek yeterince doğru değildir. Nedeni ise Türkiye'de makro tarih çalışmalarına yetkin ilgi duyulmamasıdır. Mikro analizlerde dönemin kısmi meselelerini izah ederken bazı oluşmuş (çeviri eseri) kavram kalıplarına başvurulması gerçeği II. Abdülhamit iktidarını istibdat rejimi olarak nitelendirilmesine sebep olmuştur. Dolayısıyla Türk tarihinin sosyolojik seyrini Türk sosyal biliminin makro teorik kalıplarına göre ${ }^{9}$ değerlendirmesi durumunda bu dönemin farkı bir şekilde değerlendirilmesi ihtimali vardır. Bunun yapılması için istibdadın batılı anlamda hangi manaya geldiğini Osmanlı saltanat sistemiyle Abdülhamit iktidarı arasındaki kopuşlar ve süreklilikler açısından değerlendirmeye tabi tutulması lazımdır. Hobbes'un söylediği gibi bir leviathan devletle karşı karşıya olup olmadığımızı tarihsel sosyolojinin karşılaştırmalı metotlarıyla analiz etmek durumundayız. Batıda iktidar tartışmalarının temelinde siyasi, iktisadi ve askeri ilişkiler bulunmaktadır. İdeoloji ise bu dünyevi ilişkiler perspektifinde veya sonucunda gerçekleşen hayatın anlamıyla ilgili bir seküler anlayış sistemidir. Sosyalizm, kapitalizm, demokrasi gibi ideolojik temeller seküler bir tasarı olarak değerlendirilir. Ne var ki Osmanlı saltanat sisteminin dayandığı temele baktığımızda iktisadi ilişkilerin doğurduğu bir ideolojiden ziyade dinin dünyayı anlamlandırmasıyla oluşan bir iktisadi-siyasi-askeri ilişkiler kurumsallaşması gözlemlenir. Dolayısıyla herhangi bir Osmanlı padişahının yönetim tarzını oluşturan dinamikler kendi mefhumunun içinden değerlendirilmelidir. Bu sorgulamayı önemli bir siyasi temel mesele olarak görmek kaydıyla, biz yine de meşhur tabiri kullanarak bu dönemi istibdat rejimi şeklinde adlandıracağız. Buna ek olarak araştıracağımız Cumhuriyet dönemi dini muhalefet meselesinin izlerini takip etme açısından iTC'nin dini muhalefetin dinamiklerini propaganda aracı olarak nasıl kullandığını ve böylelikle örgütlendiği gerçeğini belirtmek durumundayız.

ITC kökenlerini parlamento dışı gayrı resmi hareketlerden alır. (Zürcher, 2005; 50). Padişaha karşı bu gayrı resmi mücadeleyi Selanik merkezli faaliyetlerle çeşitli yollarda sürdürmektedir. İstibdat rejiminin baskıları karşısında gizli ve açık olarak batılılaşma endeksli yapılan bu mücadele bir kısım reformist ulema tarafından desteklemiştir. 1876-1908 arası dönem ITC'nin muhalefet tarzını anlamak için önem arz etmektedir. Bu dönemde, iTC'nin organize olma tarzlarının kademe kademe bir devrime dönen bir muhalefet eylemciliği içerdiğini söylemek hata olmaz. Son dönem Osmanlı baza alındığında modernleşme-sanayileşme politikalarının en yoğun yaşandığı dönemlerden biri, II. Abdülhamit'in

\footnotetext{
${ }^{8} \mathrm{Bu}$ anlamda Cemalledin Afgani ve Yusuf Akçura arasındaki somut ilişki kültürel milliyetçiliğin Cumhuriyet rejimiyle birlikte hâkim ideoloji olma durumuna yaptığı katkıyı düşünebiliriz. Bu ilişkinin olgusal alanda milliyetçilik ve İslam arasında enteresan bir diyalog olduğunu gösteren son derece önemli doneler bulunmaktadır. Bkz. (Küçük, 1984: 151).

${ }^{9}$ Kayalı'ya göre Türkiye'de sosyal bilim bu aşamaya henüz gelmemiştir. Bkz. (Kayalı, 2017; 601-629)
} 
padişah olduğu dönemdir. ${ }^{10}$ itttihat ve Terakki Cemiyeti'nin etkisi günden güne artmaktadır. Bu manzaranın meşruiyet zeminini teşkil eden en önemli sebep II. Abdülhamit'in baskı ve sürgün politikalarıdır. Dönemin ekser ulema ve intelijansiyası bu baskıdan kurtulmak için hürriyet ve eşitlik söylemlerine başvurmuştur. Mehmet Akif, Said Nursi gibi batılılaşma karşısında cephe oluşturma idealleri olan aydınlar da iTC'nin organize ettiği siyasal muhalefete destek vermişlerdir. Bu dönemde isyan ve ayaklanma olarak nitelendirebileceğimiz olaylar da yaşanmıştır. Ali Suavi'nin eylemleri reformist ulemanın en marjinal örneklerinden birini teşkil etmektedir. Klantin Skalyeri adında bir Ermeni'nin Abdülhamit'e suikast girişimi arkasında ITC'nin olduğu iddiaları da o dönemde muhalefetin meşruiyet şartlarını sorgulama açısından önemli örneklerdendir. Bu süreçte rejime karşı gelme tarzları açısından bir değerlendirme yapacak olursak iTC'nin muhalefet stratejilerini ikiye ayırabiliriz. (1) İsyan ve ayaklanma odaklı askeri başkaldırı ve (2) bir kısım ulema tarafından desteklenen dini muhalefet.

Teşkilatlanmanın boyutları gerek Osmanlı sınırlarının dışında gerek içinde devlet üst düzey bürokrat ve askerlerinden oluşan oldukça ciddi bir hareketlenmeyi gösteriyordu. Genellikle Avrupa ve Rumeli'de gelişen bu süreç, Enver ve Talat paşa gibi askerlerin ve Mizancı Murat, Prens Sabahattin ve Ahmet Rıza'nın entelektüel faaliyetleri ve organizasyon kabiliyetlerinin ne denli etkili ve yoğun olduğuna delildi. Esas olarak Carbonari Örgütü ve Rus nihilistlerinin örgütlenme modelleri temel alınıp öğrenciler hücreler biçiminde teşkilatlandılar. "ittihatçı gazetelerde Abdülhamit'e karşı isyan çağrılarına, onun hafiyelerine karşı şiddete başvurmanın meşru olduğuna, hürriyet mücadelesi yapan cemiyetin bunu elde etmek için her araca başvuracağına dair yazılarda özellikle 1896 yılının sonlarından itibaren belirli bir artış olduğu gözlemlenir. Yayın organlarındaki bu tür yazıların artışında, Cemiyet'in savunduğu anayasal parlamentarizmin toplumun hemen her kesimi tarafından anlaşıldığına ve desteklendiğine olan inancın verdiği özgüven etkili olmuştur." (Kaya, 2015: 85). Sadece yayın ve propaganda ile ihtilal yapılamayacağı, askerlerin yardımının zorunlu olduğu görüşünün 1902 yılındaki I. Jön Türk Kongresi'nde itirazsız kabul edilmesi, maddi açıdan zor durumda olan askerlerin Abdülhamit'i devirmeye olumlu bakacaklarına dair iyimser bir düşünceye dayanıyordu. Enver Paşa hatıralarında "Haziran'ın on iki ve on üçüncü perşembe ve cuma günleri arasındaki gecede artık Selanik'i, ailemi, istikbal-i maddimi terk ederek, sadece ahaliden bir fert gibi, hükümetin bütün kuvvetine karşı alenen, müsellahan ilan-ı isyan ediyordum" diyerek iTC'nin pratik olarak üstlendiği muhalefetin bir şekilde devlet dışı sınırlarda şekillenmeye başladığının işaretini vermiştir. Böylelikle padişahın baskı rejimini sonlandırmanın yolunu gizli teşkilatlanma, köylülerin örgütlemesi ve silahlanma yöntemleriyle gerçekleştirilmeye çalışlıyordu. (Cengiz, 2012; 61-80). ITC'nin yurt içi örgütlenmesi Selanik'te başlatılmış ve buradan bütün Rumeli'ye yayılmıştı. Cemiyetin Balkanlarda Padişaha karşı gizli bir şekilde örgütlenmesi balkanların sosyo-ekonomik koşullarına dayanmaktadır. Selanik ve Kosova'da oldukça güçlü organizasyon kudreti elde ettiler. Ancak diğer vilayetlerde yeterli oranda kudret elde edememesi olarak açıklayabileceğimiz bir eşgüdüm sorunu, birçok genç subayın bağımsız silahlı eylemlerine sebep oldu. ${ }^{11}$ Çünkü örgüt Osmanlı topraklarının geniş bir kısmında

\footnotetext{
${ }^{10} \mathrm{Bu}$ konudaki tartışmaların detayına inmek sanıyorum tezin genel muhteva seyrinden uzaklaştıracaktır. Ancak bir iki önemli noktaya temas edelim. Niyazi Berkes Abdülhamit iktidarını bir istibdat rejimi olarak nitelendirmektedir. Hatta rejime 'çok başlı leviathan' diyor. (Berkes, 2011; 403) Şöyle devam ediyor: “Bu iktidarın yapmaya çalıştı̆̆ temel şeyin 'dinin mutlak gücünü’ kurma girişimiydi. Ama aynı zamanda Düyûn-1 Umûmiye’yi kurarak batı sermayesinin Osmanlı topraklarına girişini kolaylaştırdı. Böylece Alman, İngiliz ve Fransız sermayesi özellikle demiryolları yapımının gelişimiyle Osmanlı topraklarındaki nüfuzunu artırdı. Dolayısıyla iktidar hem Osmanlı İslam geleneğini sürdürmeye çalışıp hem de batılı sermayenin nüfuzuna izin vererek bir çelişkiye düşmektedir. Bu çelişkiyi 'maddi uygarlık' ve 'manevi uygarlık' ayrımlarıyla aşmaya çalışmıştır.” (Berkes, 2011; 370-380) Ancak ne kadar başarılı olduğu ilerleyen zamanlarda görülecektir. Bu sürecin seyrini belirleme noktasında İTC'nin ve İTC'ye sempati besleyen kuşakların rejim karşıtı tavırları da önemlidir. Batılılaşma seyri, çelişkinin aşılması için uğraşılmasından çok, tedrici olarak maddi-manevi tam bir batılılaşma temayüllerinin hâkimiyet kazanması olarak gelişmiştir.

${ }_{11}$ Enver Paşa anılarında dağa çıkışını anlatırken artık ayaklanma, silahlanma ve isyan zamanının geldiğini söylüyordu ancak bu kanaatin Merkez-i Umumi'de henüz değerlendirilmediğini de ekliyordu. Paşa'nın: 'Artık meşruiyeti kuvveden fiile çıkarmaya İstaanbul'u mecbur etmek için en kestirme tedbirin umumi bir isyan icrasına vabeste olduğuna kanaat-1 kâmile hâsıl etmiştim. Fakat Merkez-i Umumi'nin bu babda kati bir planı yoktu' (Cengiz, 2012: 67) şeklindeki sözü bunu kanıtlar.
} 
nüfuzunu artırmıştı. (Çavdar, 1991; 29). Bu sorunu aşmak için Merkez-i Umumi, hükümete karşı silahlı eylem girişimlerine karar verdi.

Dini muhalefet boyutu ise sembolik muhalefet unsurları olarak kullanılabilecek meşveret, şuarayı ümmet gibi İslami ifadelerin cemiyetin genel propagandasını yapan iki önemli matbuata da isim olması gibi türlü biçimleri oluşmuştur. "iTC'nin yayınladığı hutbelerde de İstibdat yönetiminin İslam'a aykırı olduğu, Kuran'dan ayetlerle, Peygamber'in hadisleriyle ispatlanmaya çalışılmış, Abdülhamit'in halifeliğe uygun olmadığı en güçlü İslami kanıtları kullanmak suretiyle dile getirilmiştir." (Kaya, 2015: 85) "Cemiyet'in muhalif söyleminde dikkat çekici bir başka yan da bir padişah ve halife olarak Abdülhamit'le, padişah, saltanat, devlet, halifelik kavramlarını birbirinden ayırmaya çalışmasıdır. Bu çabanın temelinde, padişahlık makamına saygısından dolayı Abdülhamit'e muhalefette çekimser kaldığı düşünülen memurlar, askerler, öğrenciler, iş̧̧iler ve aydınlar gibi kamusalıklarla ilişki kurmanın kolaylaşacağı düşüncesi vardır. Bir başka ifade ile İttihatçılar Abdülhamit ile padişahlık makamı arasındaki uyumsuzluğu, özdeşsizliği yukarıda ifade edilen kamussallık biçimlerine ispat edebildiği oranda başarı kazanacağını ummuştur." (Kaya, 2015: 83)

Anadolu'da II. Meşrutiyet'in ilanından önce iTC'nin çeşitli müdahilleriyle gerçekleşen birçok isyan ve ayaklanmaların ardında yatan sebep ekonomik olmasına rağmen (Akkurt, 2014; 179-300) bu ekonomik sıkıntıların aşılması için halkın isyana ve ayaklanmaya sürükleyen asıl muharrikin diniideolojik olup olmadığını belirlemek önemlidir. Çünkü halkın ekseri umumisinin Müslüman olması, İslam'da muhalefetin temel dinamizmini şekillendirecek özelliğin ekonomik olmaktan çok itikadi olmasından dolayı, insanları taşkınlığa sürükleyen şeyin ne olduğunu açıklamak için veri eksikliği durumunu göz ardı etmemek gerek. Dolayısıyla iTC'nin halkı teşkilatlanmaya teşvik yöntemleri arasında vazifeli müftülerin yayınladığı fetvalar ve taşrada bir takım halkın saygı duyduğu ulemanın hürriyet, eşitlik ve meşrutiyet gibi yenilik anlayışlarını yücelten üsluplarıyla temel muhalefet motivasyonunu belirleyen şeyin iktisadi ilişkilerden çok dini-ideolojik, ikna-rıza süreçlerinden etkilendiği tahminini yapabiliriz. Burada, ulemanın istibdat rejimine karşı temel meşruiyet zemini kaydıracak ve hilafet anlayışını tecdit edecek bir şekilde yayınladığı birçok risale, hutbe ve fetvalar arasında, Kara'nın (1998), örnek gösterdiği metinden bahsedilebilir. Ulema-yı Din-i issâma Davet-i Şer'iye adında medrese hocalarından bir zatın 1896 yılında Mısır'da kaleme aldığı bu metnin istibdat rejimin dayanaklarına yönelik itirazlarını ve bizzat ilmiye sınıfının bu konudaki rahatsızlıklarını dillendirmesinden dönemin bir kısım ulemasının iTC'ye destek olması sonucunu çıkarabiliriz.

Anadolu ve Rumeli'de bir kısım halkın ve teşkilatlanmış İttihatçı örgütlerin Kanun-ı Esasi odaklı rejim değişikliği yönünde talepleri karşısında padişah Abdülhamit Meclis-i Mebusan'ı ikinci kez açmak zorunda kaldı. Mecliste yaptığı konuşmada otuz senelik iktidarı boyunca Osmanlı-Rus harbi sırasında kapadığı meclisi neden bu kadar geç açtığııın sebebini; halkın meşrutiyet, hürriyet ve eşitlik konusunda gerekli eğitim süreçlerinden geçemediğiyle ilgili bir eksiklikten kaynaklandığını söylüyordu. (Kansu, 2016; 24). Padişahın bu nutku çok önemlidir. Çünkü bu bakış açısı, padişahın mücadele ettiği ve kendisini muhalif bir cemiyetin meşruiyet alanı olarak tasavvur ettiği ve hayata geçirdiği meşrutiyet olarak adlandırılan anayasal düzen algısına yenik düştüğünün göstergesidir. Osmanlı siyasi sisteminin en başat konumunu içeren padişahlık makamının artık sembolik bir hal üzere seyredeceğinin en somut göstergesidir. Gencer'e göre bir tüzel kişilik olarak değerlendirilen anayasacı devlet anlayışının hâkim olması karşısında Abdülhamit'in yapabileceği pek bir şey yoktu. Çünkü bu zemini teşkil edecek şartların oluşması açısından Abdülhamit, oldukça ilginç bir şekilde "devleti tam tüzel bir iktidar aygıtına dönüştürmeye çalışarak kendi ayağına sıkmıştı." (Gencer, 2014; 776). Abdülhamit'in bu yöndeki politikaları onu modernleşme sürecinin önemli bir faili yapmaktadır. Ulemanın bu rejimi istibdat olarak nitelendirmesinin arkasında yatan dini-ideolojik sebepler aslında ortada bir dini muhalefet gerçeğinin yattığını göstermektedir. Bu anlamda meşrutiyet dönemi ulemasının muhalefet yönü modernleşme karşıtlığından ziyade istibdat karşıtlığıyla ilgilidir. "islam'da istibdat yoktur” temel söylemi çerçevesinde halifelik kurumunun peygamberi temsil ettiği ve Abdülhamit'in halifelikle uzaktan yakından alakalı olmadığı üzerine genel bir kabul vardır. Bu anlamda Abdülhamit'e yönelik İslami tepkiler aslında şeriat adına yapılıyordu. ITC'nin ideologları ise başlarda böyle bir fikre karşı açık bir itiraz getirmemiştir. Ancak 
1909 sonra iktidar aygıtına hâkim oldukları devirde Türkiye'nin istikbaliyle ilgili temel motivasyonlarının batılı-milliyetçi bir minval üzere seyrettiği gözlemlenmiştir.

\section{Mart Olayı Sonrası (1909-1919)}

31 Mart olayı, Türk devletinde otoritenin el değiştirdiğinin en kritik göstergesidir. Bu tarihten sonra muhalefet, iktidar; iktidar, muhalefet olmuştur. Bu anlamda son Osmanlı muktediri II. Abdülhamit'tir diyebiliriz. 1908 devriminin sağladığı liberal ortamda Osmanlı toplumu istibdat rejimine karşı beslediği öfkeyi tam anlamıyla boşaltmış ve sansürlenen düşünceler 31 Mart olayına kadar garip bir özgürlük anlayışıyla savrulmuştur. Ulema çevreleri de bu özgürlük ortamından yararlanarak istibdat karşıtı fikirlerini sansür dönemine göre daha net bir biçimde göstermiştir. Hürriyetin İlanı sonrası yayınlanmaya başlayan Sırat-ı Müstakim adlı derginin ilk sayfalarında Şeyhülislam Musa Kazım Efendi'nin yazısı, bu konuda reformist ilmiye çevrelerinin nasıl bir pozisyon aldıklarını göstermektedir:

"Cenâb-ı Hakk'ın avn-i samedânîsi ve ahrâr-ı ümmetin senelerden beri bezl-i mesấîsi ve ordumuzun şân-ı askerîye bi-hakkın lâyık olacak ve ile'l-ebed kulûb-i ümmetde nâ-kābil-i zevâl bir hiss-i minnetdârî ve kemâl-i ihtirâm-kârî ile yer tutacak ve târih-i Osmaniyyemizin en şanlı sahîfelerini tezyin edecek gayret-i kahramâne ve hamiyyet-i dindârânesi sâyesinde zincîr-i esâretden tahlîs-i girîbân ettik. Berât-ı hürriyet ve burhân-ı musâvâtımız olan Kānûn-ı Esâsî́mizi istirdâd ettik. Ve bunun bütün mevâdd-ı münderecesi ahkâmına harfiyyen ri'âyet edeceğimize cümlemiz yemin eyledik."(Musa Kazım, 1908:1)

Hürriyet'in ilanından sonra ITC dini daha önce bir muhalefet aracı olarak görürken artık iktidarına meşruiyet sağlayan bir imkân alanı olarak kullanmaya başlamıştır. iktidar olduğu dönemlerde yaptığı kongrelerle İslamcı çizgide çok başarılı ideolojik açıklamalar yapıyordu. Dönemin İslamcıları, Kara'ya göre 31 Mart olayı öncesi ve sonrası harplerin başladığı bir döneme kadar iTC'nin devleti ve toplumu dönüştürme projelerini şeriat adına destekleyerek, kimi ittihatçıların fark ettiği devletin seküler bir çizgiye doğru evrildiği gerçeğini göremediler. (Kara, 2014: 60). Cihan harbinde ise ITC meşruiyetini bütün bütün kaybetti ve İslamcılar enerjilerini çoğunlukla bir kurtuluş ideolojisi oluşturmaya sevk ettiler. İsmail Kara'ya göre İslamcılık hareketinin çıktığı zemin devlet nimetlerine mazhar olmuş ulema sınıfıdır. (Kara, 2014: 47). Osmanlı toplum yapısı göz önüne alınırsa ulema sınıfının bir başka kademesi daha vardır. Bunlar pasif/muhafazakâr halk hareketini temsil eden ve yönlendiren taşra ulemasıdır, diyebiliriz. Dolayısıyla İslamcılığın daha çok merkezde şekillendiği ve ideolojik olarak batılılaşma eğilimlerine temayül eden bir yönü olduğu gerçeği ilginç ve son derece önemlidir. Dini muhalefetin kaynakları açısından da merkezden çok çevrenin aktif/pasif bir rol izlediğini bu açıdan söyleyebiliriz.

Ittihad-ı Muhammedî Cemiyetinin 31 Mart olayının faili olarak suçlanması ve yayın organı Volkan dergisinin kapatılması dini muhalefet çizgisinin zayıflamasına sebep olmuştur. Ulema ve meşayıh iktidara gelen fikirlerin kendi alanlarını tehlikeye sokabileceği bir zemin oluşturacağına dair bir düşünceden dolayı tedrici bir geri durma siyaseti izlemeye başladılar. Cemiyeti IIlmiyeyi islamiye bu anlamda önemli isimleri barındırmaktadır. Bu cemiyet, Cumhuriyet devri ulemasının yetişmesini sağlayan koşulları oluşturmada etkin bir rol üstlenmiştir. Siyasal iktidarın, dini-ideolojik iktidara yönelik temayülleri ve din-devlet ayrımının sağladığı özerkleşme ve bunun üzerine inşa edilen devlet kurumsallaşmasında bu tip din adamlarının rolü büyüktür.

ITC iktidarının zaman zaman meşruiyet koşullarını kaybettiği ve iktidarını sarsan olaylar yaşadığı malumdur. Milliyetçi politikalar sonucu Trablusgarp harbi ve Balkan savaşlarına sebep olacak şartlar karşısında Meclis-i Mebusan içinde önemli tartışmalar yaşanmıştır. Neticede iTC'ye karşı parlemanto içi önemli bir muhalefet ortaya çıkmaya başlamıştır. Hizbül Cedit Hareketi olarak adlandırılan bu örgütlenme saltanat ve hilafet kurumsallaşmalarını temelinin sarsıldığını düşünerek ITC'ye ideolojik ve politik olarak ciddi bir tepki geliştirmiştir. İttihat ve Terakki içinden bir hareket olarak da değerlendirilen bu muhalefet, 23 Nisan 1911'de "Mevadd-ı Aşere" adlı bir manifesto yayınlamıştır. Bu manifesto, dini-ideolojik-etnik parçalanmışlı̆a vurgu yapan ve ittihat lafzını hak edecek şekilde davranılmasını sağlayacak bir birleştirme politikası önererek, dini muhalefetin kültürel ve kurumsal 
muhtevasını kapsayacak bazı tasarılar sunmuştur. Bu minvalde beşinci, altıncı, yedinci ve dokuzuncu maddeler önemlidir:

"5 ittihad-ı Anasır"a (Osmanlı ülkesindeki etnik unsurlar arasında kaynaşmaya) çalışılmalı, ticaret, ziraat, sanayi ve maarif ihtiyaç oranında ilerletilmelidir.

6 Dinsel ve milli ahlak ve gelenekler "muhafaza" edilmekle beraber, Batı'nın medeni ilerilikleri Osmanlı ülkesinde geliştirilmelidir.

7 Anayasa'ya (Kanun-ı Esasi) uygun olarak, Osmanlı gelenekleri sürdürülmeli ve saklı tutulmalıdır

9 Kanun-i Esasi'de hilafet ve saltanatla ilgili hakları (padişahın haklarını) güçlendirmek, bu amaçla yasama, yürütme ve yargı kuvvetleri arasındaki ilişkilerde değişiklik yapmalıdır." (Yücel, 2014: 117)

\section{Ulemanın ve Meşayıhın Tavrı}

31 Mart olayı, iTC'yi destekleyen ulemanın sükût-u hayalini temsil etmektedir. ${ }^{12}$ iTC, özellikle meşrutiyet, adalet, meşveret, müsavat gibi evrensel değerlerin İslami bir jargonda yorumlanması ve anlaşııması açısından ulema tarafından önemsenen bir teceddüt hareketini temsil ediyordu. ${ }^{13}$ Ancak ITC'nin iktidarı bu yorumlara tezat teşkil eden bazı uygulamaları ilmiye sınıfında büyük rahatsızlıklar meydana getirdi. Rumi 31 Mart 1325 ve miladi 13 Nisan 1908 tarihinde bir ayaklanma girişimi oldu. Sultanahmet meydanını dolduran kalabalığın büyük bir kısmı ilmiye sınıfındandı. Bu ayaklanmayı dini muhalefet misallerinde kılacak şartların iyi değerlendirilmesi gerekmektedir. Acaba bu isyanı teşvik eden güç ve meşruiyetine zemin hazırlayan ortam din ile mi ilgiliydi? Bu sorunu çözebilmek için olay sonrası ulemanın tavrını birkaç örnek üzerinden analiz etmek gerekmektedir.

Said Nursi'nin o dönemde ayaklanmanın ve taşkınlığın meşru olmadığı kanaatiyle askerleri itidale çağırdığı söylenir (Şahiner, 2013:107). Ulemanın çoğu da olaylar karşısında itidalli olmayı tavsiye etmiş ve isyan eden bazı askerleri teskin etmeye çalıştıkları kaynaklarda gerçekliğinde mutabakat sağlanan bir durumdur. Bazı reformist ulema çevreleri de Hürriyet'in illanıyla birlikte oldukça geniş kapsamlı bir (kültürel-kurumsal) inkılap beklentisi içerisine girmiş ve dini sembollerin değişebileceğini düşünmüşlerdir. Ancak muhafazakâr tepkileri açıklayan, dönüşümün parametrelerini belirleyen sınırlamalar devreye girmesiyle ${ }^{14}$ sembolik alanın dönüşümünden vazgeçilmiştir. Bu konuda önemli bir örneğe temas etmeden geçmek olmaz. ITC dönemi şeyhülislamlarından Hayri Efendinin tavrını tarihsel bir veri olarak iddiamıza katkı sunabiliriz:

"Hayri Bey medreseli olmakla beraber, daha Meşrûtiyet öncesinde başındaki sarığı atarak ilmiye kökeni ile bağlarını koparmış ve yıllarca Nizâmiye mahkemelerinde hâkimlik ve savcılık görevlerinde bulunmuştur. Bu yüzden onun meşihata atanması, özellikle ittihat ve Terakki içerisindeki Batıcı kesimi oldukça ümitlendirmiştir. Bunların çoğu, yeni şeyhülislâmın redinkot ve fesini muhafaza ederek meşihat makamına oturacağını sanmışlardır. Oysa, Bâb-ı Âlî Caddesi'nden geçen şeyhülislâmlık alayında arabadaki şahsın sarıklı ve şeyhülislâmların tören üniforması olan "ferve-i beyzâ" yı giymiş olduğu görülünce ümitleri boşa çıkmış ve Hayri Efendi'nin geleneğe bağlı kalacağı anlaşılmıştır" (Gürer, 2010: 1196).

Hayri Efendi'nin yaptığı sembolik alanda, dini muhtevanın gösterilmesinin mümkün olup olmadığıyla ilgili bir zemin olarak okunursa iTC'nin reformist intelijansiyası karşısında geleneksel Osmanlı kurumlarının muhafazakâr tepkisi, dönemin dini muhalefet parametrelerini gösterme açısından son derece önemlidir. Nitekim bu tepkiden rahatsız olan reformist yöneticiler istedikleri siyasi özerkleşme politikalarını gerçekleştirmek için Hayri Efendi'den sonra reformist ulemanın

\footnotetext{
${ }^{12} \mathrm{Bu}$ dönemde Osmanlı toplumunun genel olarak yaşadığı hayal kırıklıkları için bkz. (Tunaya,1998: 72-85)

${ }^{13}$ Bkz. (Kara, 1998: 10), Ulemay-1 Dini İslama Davet-i Şeriyye adlı risalede İttihat ve Terakki Cemiyeti 'Mücceddidin Hareketi' olarak değerlendiriliyor.

${ }^{14}$ Aşırı batılılaşma tepkilerine örnek olarak gösterilebilir. Daha geniş bilgi için bkz. (Mardin, 2000: 23-58)
} 
prototipi Musa Kazım Efendi'yi Bab-ı Meşihat'ın başına getirmiştir. İktidarın dini semboller alanına (imkânlarına) nüfuz etme çabası bir takım sembolik muhalefet biçimlerine sebep olmuştur. Cumhuriyet devri şapka iktisası hakkındaki kanunun karşısında duran muhafazakâr tepkiyi bu tarihsel seyri izlemeden anlamak mümkün değildir.

ITC iktidarı döneminde, Osmanlı devleti nefes alamayacak bir durumda savaşlarla uğraşıyordu. Trablusgarp savaşı ve Balkan harbi, daha sonra ise dış ve iç sorunların doğurduğu ve konjonktürden bağımsız okunamayacak Birinci Cihan harbiyle oldukça yorgun düşmüştü. Dolayısıyla batılılaşma politikaları bu dönemde önemli ölçüde kısıtlıydı. Savaş döneminin getirdiği karamsar havanın aşılabilmesi ve memleketin kurtulabilmesi için maddi tekâmül erteleniyor; manevi unsurların birleştiriciliğiyle memleket Kurtuluş Savaşına hazırlanıyordu. Bu manevi birleştiricilik ihtiyacını karşılayacak yegâne dinamik şüphesiz İslam'dı. İstanbul ve Anadolu'da 1918 sonrası askeri ve dini imkânların seferberliği söz konusu olmuştu. Bu seferberlik sırasında İstanbul'da dini ihya çabalarının kurumsallaşması adına oldukça önemli bir toplanmadan bahsetmeliyiz. Ulemanın ileri gelenlerinden meydana gelen bu müessese, Dâru'l Hikmeti'il İslâmiye'dir.

'Dâru'l Hikmeti'il İslâmiye', itttihat ve Terakki Fırkasının iktidarının son demlerinde 12 Ağustos 1334 (25 Ağustos 1918) tarihinde Cihan Harbinin sonlarında Şeyhülislam Muza Kazım Efendi'nin görevde olduğu zamanda kurulmuştur. Bu kurulun merkezden taşraya geniş bir örgütlenme oluşturduğunu söyleyebiliriz. Bir de 'Ceride-i İlmiye' adlı haftalık gazete yayınlıyordu. Albayrak'a göre bu kurul şayet günümüze kadar yaşatılmış olsaydı, İslam âlemi günümüzde yaşadığı problemlerin birçoğunu çözmüş olacaktı. (Albayrak, 2014; 13). Ancak dönemin iktidar ilişkileri analiz edildiğinde savaşların doğurduğu iktidar boşluklarından kaynaklanan bir sıçrama hareketi olarak değerlendirebileceğimiz bu kuruluş, aslında İslam dünyasının dini sorunlarını çözmek için detaylı bir sentez içermiyordu. Daha çok devlet içerisinden bir hamlenin yine devletin bir parçası olan Bab-ı Meşihat'ın kurumsal işleyişiyle ilgili bazı dönüşümleri oluşturmak için tayin, tüzük, müftülerin atanmasıyla ilgili problemler şeklinde ifade edilebilecek meselelerle uğraşıyordu. Dolayısıyla Albayrak'ın ifade ettiği gibi bir tarihsel devamlılık mümkün görünmemekle beraber mümkün olsaydı bile coğrafyanın sosyolojik gerçekliğine nüfuz edecek ve İslami şuuru ayakta tutacak bir sistem oluşturamazdı. Çünkü siyaseti ayakta tutan dini-ideolojik meşruiyet büyük oranda milliyetçilikulusalcılık kanadına doğru seyretme aşamasındaydı.

Said Nursi, Elmalıı Hamdi Yazır gibi azaların süreç sonunda geri çekildiği ve devlet-dışı merkezlerde kendi başlarına kaldıklarını görmekteyiz. Rasim Özdenören'in "Gül Yetiştiren Adam" adlı romanında Elmalıı'yı anlattığı söylenir. Burada çizilen ulema-din adamı profili aslında Cumhuriyet dönemi ulemanın da prototipidir. Hem reformist ulema hem geleneksel ulema hem de mutasavvıf zevattan bir kısım, bu devirde bir "geri çekilme" timsali oluşturmuşlardır. ${ }^{15}$ Bu durumun "hayal kırıklıklarıyla' alakalı olduğunu söyleyebiliriz. Batılılaşma ya da 'batılılaştırma'(Meriç, 1983: 234) cereyanları bu coğrafyanın dinamiklerini büyük ölçüde dönüştürdükçe Osmanlı dini-ideolojik meşruiyeti temsil eden mevcut ulemanın meşruiyeti kademe kademe kamusal alandan uzaklaşmıştır. Bir başka ifadeyle her dönüşüm projesi karşısında umutlar besleyen i̇slami aydınlar dönüşümün tahminlerini aşan sonuçlar doğurduğunu gözlemledikçe karşılarına çıkan bu 'tedrici batılılaşma' durumuna cevap vermekte yeterli olamamışlar ve nüfuzları büyük oranda kırılmıştır.

Mutasavvıflar (Meşayıh) bu dönüştürme projeleri karşısında sadece ideolojik-dogmatik alana dokunabilecek temel düsturların muhafızı olarak siyaset dışı tekke, cami, cemiyet ve bir takım neşriyat imkânlarını kullanarak kültürel ve zaman zaman politik ihyayı sağlamak için sessiz ve etkin bir sürecin failleri olmuştur. Bu anlamda Ceride-i Sufiye ve itisam, Muhibban gibi gazete ve dergiler tasavvufi neşriyatın önemli örnekleri arasındadır. Bu neşriyat daha çok dogmatik alandaki değişim karşısında sebatkâr (hatta muhafazakâr) bir karşılama girişimi olarak bir sembolik muhalefeti muhteva eder.

Bu sıralarda Ziya Gökalp adında bir 'sentezci' (Karakaş, 2007) entelektüelin yazılarında müftülük gibi meşihat işlerinde bulunan zatların kadılık görevlerini ifa edemeyeceğini belirterek siyasal

\footnotetext{
${ }^{15}$ Bkz. (Özdenören, 2016)
} 
iktidarın yargı mekanizmasını dini iktidarın yükümlülüğünden çıkararak laik bir özerk siyasal iktidar tasavvur etmesi, Osmanlı devletinde köklü ve tedrici dönüşümlerin oluştuğu gerçeğini yansıtmaktadır. (Gürer, 2010: 1195) Ziya Gökalp'in meşihat adlı manzumesi bu konuda önemli bir zihniyet değişimini öngörmektedir. Kanun- Esasiyle birlikte siyasal iktidarın meşruiyetini sağladığı zemini, değişmez, sabit bir hükmü temsil eden şer'i yasa değil milletin demokratik konsensüsüyle sağladığı bir anayasa sağlayacaktır. Bu dönüşüm dogmatik alanı oluşturan değerlerin değişimiyle ilgili son derece kritik bir sürece girildiğinin göstergesidir. Bir başka yönden bu, Türk devletinin gayr-ı müslim halkla Tanzimat'tan bu yana reforme ettiği dini-etnik iktidar ilişkilerini yeniden temin etme adına atılan bir adımdır.

İsmail Kara'ya göre bu süreçte en güçlü dini muhalefet, merkezin fikri tartışmalarıyla yoğrulan batılılaşma endeksli İslamcılardan ziyade "taşrada, halk katında ve ilmiye sınıfı ile tarikat çevrelerinin alt katmanlarında kendine mahsus şifahi kanallarla işlemektedir." (Kara, 2014; 10). Bu kanaatin temelinde muhalefetin seyrinin hangi minval üzere olduğuyla ilgi önemli bir ön anlama vardır. Tepkilerin katıksız İslami veya dini oluşunu tasvir edebilecek yegâne unsur, merkezin yoğun bilim, pozitivizm, akıl, aydınlanma gibi batılı hususlarla ilgili tartışmalarında uzak, kendi yağında kavrulan, kendi biçimini tasavvur eden, kendi şarkısını söyleyen ve kimi uzlette, kimi sürgünde olan ulemadan veya meşayıhtan bir kısım zevat ve onları takip eden dindar halktır. Bu muhalefet örneklerini Meşrutiyet dönemindeki biçimleriyle Cumhuriyet dönemindeki biçimleri arasında büyük paralellikler kurmak sanıyorum yanlış olmayacaktır. Bu arada böylesine bir tepki tarzı ile Scoot'un gizli senaryo şeklinde ifade ettiği bir direniş biçiminden de oldukça farkıdır. Gizli senaryo varsayımı, tabii olanlar arasında yaygın bir iletişimsel eylemdir. Ancak tabiiyet devam etmektedir. Tabii olanlar büyük oranda hala esirdir. (Scoot, 2014: 74) Türkiye'de geleneksel kurumların batılı akımlardan uzak kendi hallerinde, kendi toplumsal iktidarlarını kurmaya çalışmaları bir gizli senaryo örneği değildir. Bunun için hem II. Meşrutiyet iktidarı hem de Cumhuriyet iktidarı bu ideolojik özerkleşme temayülleri karşısında oldukça sert bir tepki geliştirmiştir. Bu sadece dini muhalefet cephesinde değil, aynı zamanda etnik kalkışmalar karşısında da son derece baskın bir eğilimdir. (Bozaslan, 2015: 272; Çeğin, 2014: 32)

\section{Sonuç}

Osmanlı devletinin boğuştuğu sorunlarla devlet içerisinden farklı alanlara nüfuz ederek kurumların işlemeyen taraflarını tamir etmeyi içeren ıslahat politikaları baş göstermiştir. Osmanlı İmparatorluğu'nun ordu içinde girişmiş olduğu az sayıdaki ilk reformlarda ifadesini bulan "ıslahat" fikri Cumhuriyet devrinde "inkılap" fikrine çevrilmiştir (Karpat, 2010,79). Bu süreç batıılıaşma fikirlerinin de kendi aralarındaki mücadelelerle işlemiş ve devletin temel özelliklerini değiştirmeye dayalı bir modernleşme projesi olarak Cumhuriyet'in kurulmasıyla sonlanmıştır. Batılılaşma ve modernleşme fikriyatının oluşturduğu bir dini muhalefet bilinci Osmanlı hanedanının siyasal iktidarını dönüştürmüştür. Artık toplumsal güç dinamiklerinin temsil ve karar işleyişini kurumsallaştıran devlet mekanizması, en azından bürokratik-örgütsel düzeyde dinin cumhuriyetçi ve hürriyetçi yorumlaması paralelinde tam batılı bir tarzda işleyecektir. Dolayısıyla artık muhalefetin meşruiyet seyri farklı bir merkezde şekillenecektir. Bir başka ifadeyle muhalefet bilincini yaratan ideolojik meşruluk koşulları artık, kimi alanlarda kısmen kimi alanlarda bütünüyle Osmanlı toplumsal iktidar mekanizmasını oluşturan unsurlar olacaktır. Bu merkezi açıklayabilecek yegâne unsur ise bireysel ihya mekanizmalarıdır. İhyanın sağlanması açısından bir değerlendirme bizi tasavvuf ve kelam düşüncesinin kalbi muhalefet gerçekliğini barındıran inanç dünyalarını şekillendirme çabalarının gizli faaliyetlerine yoğunlaşmamız gerektiğine götürmektedir.

\section{Kaynakça}

Akkurt, Halil (2014), "Anadolu'da İttihat ve Terakki Cemiyeti (1906-1912): Genel Bir Çerçeve", AïÜ Sosyal Bilimler Enstitüsü Dergisi, 2014, Cilt:14, Yıl:14, Sayı:2, 14: 279-304.

Albayrak, Sadık (2014), Son Devrin İslam Akademisi ‘Dâru’l Hikmeti'il İslâmiye', İstanbul: İz Yayıncılık.

Barbalet, J. M. (1985), Power and Resistance, The British Journal of Sociology, Vol. 36, No.4, pp. 531548. 
Berkes, Niyazi (2011), Türkiye'de Çağdaşlaşma, İstanbul: Yapı Kredi Yayınları.

Bozarslan, Hamit (2015), İmparatorluktan Günümüze Türkiye Tarihi, İstanbul: Iletişim Yayınları.

Cengiz, Halil Erdoğan (2012), Enver Paşa'nın Anlıları, İstanbul: İş Bankası Yayınları.

Çavdar, Tevifk (1991), İttihat ve Terakki, İstanbul: Illetişim Yayınları.

Çeğin, Güney (2014), “Erken Cumhuriyet Döneminde Rejimin Militarist Özerkliği, Der. Güney Çeğin, İbrahim Şirin, Türkiye'de Siyasal Şiddetin Boyutları içinde, İstanbul: illetişim Yayınları.

Gencer, Bedri (2014), İslam'da Modernleşme (1839-1939), İstanbul: Doğu Batı Yayınları.

Gürer, Ahmet Şamil (2010), “ittihat ve Terakki'nin Bir Fırka Şeyhülislamı Arayışı ve Musa Kazım Efendi'nin Şeyhülislamlığa Getirilişi”, Turkish Studies, Volume 5/4, pp. 1186-1206.

Heper, Metin (2012), Türkiye'de Devlet Geleneği, İstanbul: Doğu Batı Yayınları.

Kansu, Aykut (2016), itttihatçıların Rejim ve İktidar Mücadelesi 1908-1913, İstanbul: İletişim Yayınları.

Kara, İsmail (1998), “Ulema-Siyaset İlişiklerine Dair Önemli Bir Metin: Muhalefet Yapmak Muhalefete Katılmak", Divan Dergisi, S.1, s. 1-25.

Kara, İsmail (1999), "Ulema-Siyaset iliş̧kilerine Dair Metinler II: Ey Ulema Bizim Gibi Konuş!", Divan Dergisi, S.2, s. 65-134.

Kara, İsmail (2014), İslamcıların Siyasi Görüşleri I, İstanbul: Dergâh Yayınları.

Karakaş, Mehmet (2007), Türk Ulusçuluğunun İnşası, Ankara: Elips Yayınları.

Karasipahi, Sena (2009) "Comparing Islamic Resurgence Movements in Turkey and Iran", Middle East Journal, Vol. 63, No. 1, pp. 87-107.

Kaya, Gökhan (2015), “Eleştirel Söylem Tutumundan Karşıt Kamusal Alan Yaratmaya Geçiş: İttihat ve Terakki Cemiyeti'nin II. Abdülhamit'e Muhalefeti", Amme Idaresi Dergisi, Cilt 48, Sayı 2, Haziran 2015, s. 73-103.

Kayalı, Kurtuluş (2017), “Son Dönem Yerli Sosyal Bilimler Çalışmalarında 1908 Devrimi'nin Tahlili”, 100. yılında Jön Türk Devrimi içinde, Haz. Sina Akşin, Sarp Balcı, Barış Ünlü, İstanbul; Türkiye İş Bankası Kültür Yayınları.

Küçük, Yalçın (1984), Aydın Üzerine Tezler -2, Ankara: Tekin Yayınevi.

Lukes, Steven (2016), İktidar: Radikal Bir Görüş, çev. Mehmet Ratip, İstanbul: İletişim Yayınları.

Mann, Micheal (2012), ỉktidarın Tarihi, Cilt 1, çev. Ali Rıza Güngen, Gülben Şaş, Ankara: Phoenix Yayınevi.

Mardin, Şerif (2000), "Tanzimattan Sonra Aşırı Batılılaşma”, Ed. Ersin Kalaycıoğlu, Ali Yaşar Sarıbay, Türkiye'de Politik Değişim ve Modernleşme içinde, İstanbul: Alfa Yayınları.

Meriç, Cemil (1983), "Batılaşma”, Cumhuriyet Dönemi Türkiye Ansiklopedisi içinde, İstanbul: illetişim Yayınları, ss.234-238.

Musa Kazım Efendi (1908), "Hürriyet, Müsavat", Sırat-ı Müstakim Mecmuası Meşrutiyetten Cumhuriyete Yakın Tarihimizin Belgesi 1 içinde, İstanbul: Bağcılar Belediyesi Yay.

Mustafa, Nevin Abdülhalık (2001), İslam Siyaset Düşüncesinde Muhalefet, Çev. Vecdi Akyüz, İstanbul: Ayışığı Kitapları.

Özdenören, Rasim (2016), Gül Yetiştiren Adam, İstanbul: İz Yayıncılık.

Scoot, J. C. (2014), Tahakküm ve Direniş Sanatları, Çev. Alev Türker, İstanbul: Ayrıntı yayınları. 
Şahiner, Necmeddin (2013), Bilinmeyen Taraflarıyla Bediüzzaman Said Nursi, İstanbul: Nesil Yayınları. Şeker, Fatih (2013), Osmanlı İslam Tasavvuru, İstanbul: Dergâh Yayınları.

Tunaya, Tarık Zafer (1998), Hürriyetin İlanı: İkinci Meşrutiyetin Siyasi Hayatına Bakışlar, İstanbul: Cumhuriyet Kitap.

Uludağ, Süleyman (2012), İslam Düşüncesinin Yapısı: Selef, Kelam, Tasavvuf, Felsefe, İstanbul: Dergâh Yayınları.

Yücel, Yiğit (2014), "Itttihat ve Terakki Fırkası İçinde Parti İçi Muhalefet; Hizb-i Cedit Hareketi", Çağdaş Türkiye Tarihi Araştırmaları Dergisi, XIV/28 (2014-Bahar), s.103-125.

Zürcher, Erik Jan (2005), Savaş, Devrim ve Uluslaşma Türkiye Tarihinde Geçiş Dönemi (1908-1928), Çev. Ergün Aydınoğlu, İstanbul: Bilgi Üniversitesi Yayınları. 